\title{
Teaching physics students of humanitarian-oriented groups in the Middle Years Programme (basic school) of the International Baccalaureate
}

\author{
Viktor S. Kornilov ${ }^{1}$, Olga V. Lvova ${ }^{1}$, Igor S. Obolensky ${ }^{2}$ \\ ${ }^{1}$ Moscow City Pedagogical University \\ 29 Sheremetyevskaya St., Moscow, 127521, Russian Federation \\ ${ }^{2}$ School No. 1389 of Moscow \\ 10 Nikulinskaya St., Moscow, 119602, Russian Federation
}

Problem and goal. In 1968, an international non-governmental organization of the International Baccalaureate with consultative status with UNESCO was established in Switzerland [11; 26; 27; 29-31]. The methodological basis of the International Baccalaureate is intercultural communication, communication, self-development, conceptual thinking, learning efficiency, etc. The International Baccalaureate is an internationally recognized curriculum and is implemented worldwide, including in Russia (Vladivostok, Moscow, Moscow region, Perm, Samara, Saint Petersburg, Ulyanovsk). In addition, International Baccalaureate diplomas are recognized by many foreign educational institutions.

In the process of teaching physics to students of humanitarian-oriented groups on the Middle Years Programme (MYP) (basic school) of the International Baccalaureate, some students have difficulties both in mastering the theoretical material and in solving educational text problems.

In this connection, to improve the efficiency of training of such students it is advisable not only to carry out a theoretical justification of the possibility of using methods of adaptation of texts of problems in physics and to develop adapted educational tasks with their subsequent inclusion in the content of training, but also to use modern information technologies both in the presentation of theoretical material to students (multimedia teaching tools, electronic resources, etc.) and to teach students to use computer programs ("Live physics", "Laboratory L-micro", "1C: Tutor in physics", "Physics course of the XXI century", "Open physics", "Physics in animations", "Physics. Grades 7-11. Workshop", etc.).

Obviously, that it is necessary in the future to carry out experimental and pedagogical activities revealing the effectiveness of teaching physics.

Methodology. The effectiveness of teaching physics to schoolchildren of humanitarianoriented groups under the MYP (basic school) of the International Baccalaureate will be largely provided by the developed content of training, the implementation of didactic principles of training, the implementation of a system-activity approach in teaching, the informatization of training, linguistic analysis of the content of educational tasks, the implementation of technological approach to the design of the educational process, taking into account the peculiarities of psychological laws of formation of mental actions of schoolchildren in the process of solving physical problems $[1 ; 3 ; 7-9 ; 12-16 ; 19 ; 20 ; 28]$.

(C) Kornilov V.S., Lvova O.V., Obolensky I.S., 2019 
Results. Application of the method of adaptation of the text of educational tasks, the use of informatization tools, the use of various algorithms for solving physical problems, linguistic analysis of the content of educational tasks helps to improve the quality of teaching physics to students of humanitarian-oriented groups under the MYP (basic school) of the International Baccalaureate.

Conclusion. The use of an adapted format for the presentation of educational problems, various algorithms for solving physical problems, the use of modern information technologies for teaching physics to students of humanitarian-oriented groups under the MYP (basic school) of the International Baccalaureate contributes to the increase in students' interest in learning and the formation of their fundamental system of subject knowledge in physics.

Key words: Middle Years Programme (basic school) of the International Baccalaureate; information technology; informatization of physics training; algorithms for solving physical problems; students of humanitarian-oriented groups

Problem statement. The Middle Years Programme (MYP) (basic school) of the International Baccalaureate is designed for students between the ages of 11 and 16. When studying under this program, students show their best qualities develop their creativity, logical and conceptual thinking, the ability to formulate and articulate their thoughts, the ability to achieve intercultural understanding and dialogue, and other qualities.

Structurally, MYP consists of eight subject groups: foreign language education, native language and literature, human and society, natural sciences (chemistry, ecology, agronomy, mathematics, astronomy, physics, etc.), mathematics, art, design, physical culture and health.

If we talk about teaching physics (8-9 grade, which corresponds to 4-5 years of study), such training is carried out in the format of related concepts, concepts and research $[4-6 ; 17 ; 21-23 ; 26 ; 27 ; 29-31]$. This corresponds to the fact that in the process of teaching the student is asked questions to which he gradually has to find an answer, studying all the necessary educational information on this topic. In this case, as a rule, the answer to the question may contain information from several sections of physics.

Given these features of the MYP physics course [24-27; 29-31], and also features of development of the child at the age of $13-16$ years $[2 ; 10 ; 18]$, we will highlight the most difficult aspects in teaching physics.

Aspect 1. Complexity of mathematical apparatus (for example, nonlinear dependencies, systems of algebraic equations, trigonometric equations, elements of vector algebra, function graphs).

Aspect 2. Difficulties in mastering the training material (e.g. uniform and uniformly accelerated motion, geometric optics and wave optics, classical and relativistic mechanics, classical and quantum physics).

Aspect 3. Difficulties of visual perception (e.g. thermal phenomena, electrical circuits, electromagnetic field, atomic or nuclear physics).

Method of research. Currently, students of Russian schools are required to pass the state final certification at the end of grade 9 , regardless of what program they studied during the primary school. In this regard, the goals and objectives of 
teaching physics are determined simultaneously by two standards: the Federal State Educational Standards of the Russian Federation of Basic General Education [24; 25] and MYP Science guide [29-31].

Upon completion of the International Baccalaureate MYP (basic school) physics education, students must achieve certain results, such as:

- personal (the presence of the formation of cognitive interests, developed intellectual and creative abilities, the presence of confidence in the possibility of knowledge of nature, skills and self-acquisition of subject knowledge);

- metasubject (the presence of skills and abilities of self-acquisition of new knowledge; be able to independently set a goal, to evaluate the results of their activities, to anticipate the results of their actions; to understand the difference between the original facts and formed hypotheses, theoretical models and real objects);

- subject (should be able to organize their own observations, plan and carry out experiments, process and analyze the results of their measurements, to present the results of their measurements in the form of formulas, graphs or tables; be able to independently see the different relationships between physical quantities, analyze the results and make appropriate logical conclusions, etc.).

In addition, one of the results of such training should be a developed profile of the student of the International Baccalaureate (IB learner profile). IB student profile is the mission of the International Baccalaureate, which is expressed by a set of learning outcomes that meet the requirements of the XXI century.

To achieve the required results of teaching physics under the MYP (basic school) of the International Baccalaureate were implemented:

- system-activity approach, developed in the works of B.G. Ananiev, A.G. Asmolov, L.S. Vygotsky, P.Ya. Galperin, V.V. Davydov, L.V. Zankov, A.N. Leontiev, B.F. Lomov, A.R. Luriya, V.V. Rubtsov, D.B. Elkonin and other authors;

- general didactic principles and criteria for optimizing the organization of training, developed in the works of Yu.K. Babansky, V.P. Bespalko, V.I. Zagvyazinsky, B.C. Ilyin, B.C. Lednev, I.Ya. Lerner, M.N. Skatkin, A.V. Usova and other authors;

- approaches to informatization of education, developed by C.G. Grigoriev, V.V. Grinshkun, E. Dijkstra, O.Yu. Zaslavskaya, D. Collins, A.A. Kuznetsov, I.V. Levchenko, S.V. Panyukova, A.Yu. Uvarov, B. Hunter and other authors;

- multimedia teaching tools, computer programs ("Live physics", "Laboratory L-micro", "1C: Tutor in physics", "Course of physics of the XXI century", "Open physics", "Physics in animation", "Physics. Grades 7-11. Workshop", etc.);

- interdisciplinary connections that have devoted their studies R.L. Isaeva, S.B. Kaplan, A.E. Kirichenko, J.M. Kotlyar, A.A. Kuznetsova, G.M. Morozov, N.K. Ruzin, A.A. Carpenter, V.N. Fedorova, N.V. Chkhaidze and other authors;

- psychological regularities of formation of mental actions and of the process of solving physics problems, which study found reflection in the works of G.A. Balla, G.J. Halperin, B.K. Damitov, G.S. Kostiuk, A.N. Leontiev, E.I. Machuca, A.S. Pantini, N.F. Talyzina, L.M. Friedman, A.F. Esaulov and other authors;

- constructing the learning process through a technological approach, which development has made the works of V.N. Ardasheva, V.P. Bespalko, T.A. Bohr, M.V. Klarina, G.K. Selevko and other authors; 
- linguistic analysis of the content of educational tasks in physics for students in grades 8-9, which initiates approaches to the formation of a system of educational tasks (the problem should have a clear application, the student should not remain indifferent to the problem, the problem can have a beautiful and modern design, the problem should be formulated briefly and other approaches).

It should be noted that the theoretical study of questions of development of physics problems and use them in educational process were considered in the researches of V.I. Danilchuk, A.S. Kondratyev, I.Ya Lamina, V.G. Razumovsky, V.A. Marchenkova, V.V. Voroshilov, A.S. Kopylov, A.M. Afanas'ev and other authors. To the substantiation of the need and description of the features of the use of text problems in teaching physics in the framework of the program of primary and high school are devoted the works of D.A. Alexandrov, I.M. Shvaychenko, S.E. Kamenetsky, V.P. Orekhov, A.S. Kondratiev, V.I. Sosnovsky, M.P. Golubovskaya, V.I. Volodarsky, S.Yu. Trofimova, S.V. Bublikova, V.A. Larchenkova and other authors.

The need for the use of adapted texts of problems in the physics lessons of the main school in the classes of non-physical and mathematical profile is justified by three main assumptions. Set them out.

1. It becomes much easier for students to overcome difficulties in mastering the theoretical material, and they will be able to solve at least the tasks of the initial level.

2. Successful practice of solving problems with adapted texts will allow students to learn theoretical material that was previously difficult to master on one or several specific examples.

3. Understanding the content and meaning of the text problem, and, consequently, the search for a solution to the text problem becomes easier if the area of knowledge is close to the student.

The need for the use of information technology, with which it is possible to organize computer illustrations and animations, is based on the fact that allows students to understand and remember the educational material; to demonstrate in the classroom to students fundamental experiments that can not be shown without the use of a computer, for example, movement in the form of models and graphic descriptions, dynamic models of phenomena, fundamental experiments, etc.; to organize independent cognitive activity of students both in and out of school hours.

In addition, the use of information technology helps school teachers to conduct classes and monitor the performance of students.

Results and discussion. The validity and reliability of the results are based on the theory and practice of pedagogical and psychological science, the theory and methodology of teaching physics in school, the theory and practice of informatization of education, the correctness of the methods and approaches used to teach physics to students of humanitarian-oriented groups under the MYP (basic school) of the International Baccalaureate.

The approbation of the developed technique in the course of teaching physics to schoolchildren was carried out. It was confirmed the hypothesis that the use of adapted for a specific group of students presentation format of tasks contributes to 
increasing the interest of students in the study of the subject of physics, better assimilation of the subject.

We formulate guidelines for the adaptation of the text of problems in physics for students in grades 8-9, enrolled in the MYP (basic school) of the International Baccalaureate:

1) the task should be close to the student or group of students;

2) the task should evoke emotions;

3) similar tasks are recommended to be combined in a series of tasks;

4) further targeting and narrowing the target audience as students become acquainted;

5) design tasks, block structure;

6) registration, figures.

It is also necessary to draw the following conclusions.

1. Adapted tasks more closely and emotionally to meet in classrooms. As a result, against the background of the interest shown to the problems, students receive the necessary knowledge on the subject.

2. In the case of complex material adapted tasks, despite the lack of understanding of the topic, retain interest in the subject, which is important for further study of the subject.

3. Adapted problems do not always lead to an increase in the average score in the class. The identified deviations are usually associated with the individual characteristics of the student (absence from several classes in a row, participation in Olympiads or major events the day before, the proximity of the end of the training module, the time of the lesson, the absence of a calculator).

4. The use of adapted problems imposes the need for additional training time to move from solving adapted problems to solving problems in the classical formulation.

Conclusion. If in the process of teaching students to use adapted to a specific group of students the format of tasks, use information technology, it will increase the interest of students in the study of the subject of physics, better assimilation of the subject.

\section{References}

[1] Babanskiy Yu.K. Optimizatsiya protsessa obucheniya [Optimization of the learning process]. Moscow: Pedagogika Publ., 2007. 103 p.

[2] Bozhovich L.I. Lichnost $i$ eye formirovaniye $v$ detskom vozraste [Personality and its formation in childhood]. Saint Petersburg: Piter Publ., 2008. 400 p.

[3] Borovskikh T.A. Konstruirovaniye uchebnogo protsessa na osnove tekhnologicheskogo podkhoda [Design of educational process on the basis of technological approach]. Integratsiya obrazovaniya [Integration of education]. 2011. No. 1(62). Pp. 67-73.

[4] Gendenshteyn L.E., Bulatova A.A., Kornilyev I.N., Koshkina A.V. Fizika. 9 klass: uchebnik: $v 2$ ch. Ch. 1 [Physics. Grade 9: textbook: in 2 parts. Part 1]. Moscow: Laboratoriya znaniy Publ., 2019. 224 p.

[5] Gendenshteyn L.E., Bulatova A.A., Kornilyev I.N., Koshkina A.V. Fizika. 9 klass: uchebnik: v 2 ch. Ch. 2 [Physics. Grade 9: textbook: in 2 parts. Part 2]. Moscow: Laboratoriya znaniy Publ., 2019. 144 p. 
[6] Gendenshteyn L.E., Kaydalov A.B., Kozhevnikov V.B. Fizika 9 klass: uchebnik [Physics. Grade 9: textbook]. Moscow: Mnemozina Publ., 2012. 273 p.

[7] Grinshkun V.V. Kachestvo informatsionnykh resursov i professionalnyye kachestva pedagogov. Vzaimosvyaz i problemy [Quality of information resources and professional qualities of teachers. Interrelation and problems]. Informatika i obrazovaniye [Informatics and education]. 2013. No. 1(240). Pp. 79-81.

[8] Grinshkun V.V. Informatizatsiya kak znachimyy komponent sovershenstvovaniya sistemy podgotovki pedagogov [Informatization as an important component of improving the system of teacher training]. Vestnik Moskovskogo gorodskogo pedagogicheskogo universiteta. Serija: Informatika i informatizacija obrazovanija [Bulletin of the Moscow City Pedagogical University. Series: Informatics and Informatization of Education]. 2014. No. 1(27). Pp. 15-21.

[9] Grinshkun V.V. Sushchestvuyushchiye podkhody k ispolzovaniyu sredstv informatizatsii pri obuchenii estestvenno-nauchnym distsiplinam [Existing approaches to the use of informatization tools in teaching natural sciences]. Vestnik Moskovskogo gorodskogo pedagogicheskogo universiteta. Serija: Informatika i informatizacija obrazovanija [Bulletin of the Moscow City Pedagogical University. Series: Informatics and Informatization of Education]. 2014. No. 4(30). Pp. 8-13.

[10] Duek K. Gibkoye soznaniye: novyy vzglyad na psikhologiyu razvitiya vzroslykh i detey [Flexible consciousness: a new look at the psychology of development of adults and children]. Moscow: Mann, Ivanov i Ferber Publ., 2013. 400 p.

[11] Kondakov A.M. Mezhdunarodnyy bakalavriat i rossiyskaya shkola: normativno-metodicheskaya dokumentatsiya dlya rossiyskikh obrazovatelnykh uchrezhdeniy [International Baccalaureate and Russian school: regulatory and methodological documentation for Russian educational institutions]. Moscow: Molodaya gvardiya Publ., 1997. 51 p.

[12] Kornilov V.S. Metody ratsionalnykh rassuzhdeniy v obuchenii obratnym zadacham dlya differentsialnykh uravneniy [Methods of rational reasoning in teaching inverse problems for differential equations]. Vestnik Moskovskogo gorodskogo pedagogicheskogo universiteta. Serija: Informatika i informatizacija obrazovanija [Bulletin of the Moscow City Pedagogical University. Series: Informatics and Informatization of Education]. 2005. No. 2(5). Pp. 63-66.

[13] Kornilov V.S. Gumanitarnaya komponenta prikladnogo matematicheskogo obrazovaniya [Humanitarian component of applied mathematical education]. Vestnik Moskovskogo gorodskogo pedagogicheskogo universiteta. Serija: Informatika i informatizacija obrazovanija [Bulletin of the Moscow City Pedagogical University. Series: Informatics and Informatization of Education]. 2006. No. 2(7). Pp. 94-99.

[14] Kornilov V.S. Obratnye zadachi v soderzhanii obucheniya prikladnoj matematike [Inverse problems in the content of teaching applied mathematics]. Vestnik Rossijskogo universiteta druzhby narodov. Serija: Informatizacija obrazovanija [Bulletin of Peoples' Friendship University of Russia. Series: Informatization of Education]. 2014. No. 2. Pp. 109-118.

[15] Kornilov V.S. Realizacija nauchno-obrazovatel'nogo potenciala obuchenija studentov vuzov obratnym zadacham dlja differencial'nyh uravnenij [Realization of scientific and educational potential of training of students of higher education institutions in the inverse problems for the differential equations]. Kazanskij pedagogicheskij zhurnal [Kazan pedagogical journal]. 2016. No. 6. Pp. 55-59. [16] Kornilov V.S. Teorija i metodika obuchenija obratnym zadacham dlja differencial'nyh uravnenij: monografija [Theory and technique of training to the inverse problems for differential equations: monograph]. Moscow: OntoPrint Publ., 2017. 500 p.

[16] Kornilov V.S. Teorija i metodika obuchenija obratnym zadacham dlja differencial'nyh uravnenij: monografija [Theory and technique of training to the inverse problems for differential equations: monograph]. Moscow: OntoPrint Publ., 2017. 500 p.

[17] Krivchenko I.V. Fizika 9 klass: uchebnik [Physics. Grade 9: textbook]. Moscow: Laboratoriya znaniy Publ., 2015. 150 p. 
[18] Levshunova Zh.A., Artyukhova T.Yu. Vozrastnyye osobennosti osoznannoy samoregulyatsii proizvolnoy aktivnosti v period ranney yunosti [Age peculiarities of conscious self-regulation of voluntary activity in the period of early youth]. Vestnik Kemerovskogo gosudarstvennogo universiteta [Bulletin of Kemerovo State University]. 2015. Vol. 1. No 3. Pp. 102-106.

[19] Miroshkina M.R. X, Y, Z. Teoriya pokoleniy. Novaya sistema koordinat [X, Y, Z. Theory of generations. A new coordinate system]. Voprosy vospitaniya [Problems of education]. 2014. No. 2. Pp. 50-57.

[20] Penrouz R. Novyy um korolya: o kompyuterakh, myshlenii i zakonakh fiziki [New mind of the king: On computers, thinking and the laws of physics]. Moscow: URSS Publ., 2011. 400 p.

[21] Peryshkin A.V. Fizika: 9 klass: sbornik zadach po fizike [Physics: grade 9: collection of problems in physics]. Moscow: Ekzamen Publ., 2010. 195 p.

[22] Peryshkin A.V. Fizika: 8 klass [Physics: grade 8]. Moscow: Drofa Publ., 2013. 237 p.

[23] Peryshkin A.V., Lontsova G.A. Fizika: 8 klass: uchebnik [Physics: grade 8: textbook]. Moscow: Drofa Publ., 2017. 160 p.

[24] Federalnyy gosudarstvennyy obrazovatelnyy standart osnovnogo obshchego obrazovaniya: utv. prikazom Minobrnauki RF ot 29 dekabrya 2014 g. No. 1644 [Federal State Educational Standard of Basic General Education: approved by order of Ministry of Education and Science of the Russian Federation of 29 December 2014 No. 1644]. http://www.edu.ru/db/mo/Data/d_14/m1644.html (accessed: 20.03.2019).

[25] Federalnyy zakon ob obrazovanii v Rossiyskoy Federatsii: utv. prikazom Gosudarstvennoy dumy RF ot 29 dekabrya 2012 g. No. 273-FZ (red. ot 03.08.2018) [Federal Law on Education in the Russian Federation: approved by order of the State Duma of the Russian Federation of 29 December 2012 No. 273-FZ (as amended on 03.08.2018)]. http:// www.consultant.ru/document/cons_doc_LAW_140174/(accessed: 20.03.2019).

[26] Chto takoye Mezhdunarodnyy bakalavriat $i$ kak rabotayet nasha shkola [What is the International Baccalaureate and how our school works]. https://infourok.ru/chto-takoe-mezhdunarodniy-bakalavriat-i-kak-rabotaet-nasha-shkola-3160569.html (accessed: 20.03.2019).

[27] Chto takoye programma Mezhdunarodnogo bakalavriata (IB)? [What is the International Baccalaureate (IB) program?] https://www.globaldialog.ru/articles/chto-takoeib/ (accessed: 20.03.2019).

[28] Esaulov A.F. Psikhologiya resheniya zadach [Psychology of problem solving]. Moscow: Vysshaya shkola Publ., 1972. 217 p.

[29] IB Middle Years Programme. https://istudy.com.ru/ib/ib-myp.html (accessed: 20.03.2019).

[30] MYP: From principles into practice. http://www.ibo.org/ (accessed: 20.03.2019).

[31] MYP Science guide. https://www.spps.org/site/handlers/ filedownload.ashx?moduleinstanc eid $=38378 \&$ dataid $=21234 \&$ FileName $=$ sciences_guide_2014.pdf (accessed: 20.03.2019).

\section{Article history:}

Received: 10 April 2019

Accepted: 20 May 2019

\section{For citation:}

Kornilov V.S., Lvova O.V., Obolensky I.S. (2019). Teaching physics students of humanitarian-oriented groups in the Middle Years Programme (basic school) of the International Baccalaureate. RUDN Journal of Informatization of Education, 16(3), 270-280. http:// dx.doi.org/10.22363/2312-8631-2019-16-3-270-280

\section{Bio notes:}

Viktor S. Kornilov, doctor of pedagogical sciences, candidate of physical and mathematical sciences, full professor, deputy head of the department of informatization of education of the Moscow City Pedagogical University. Contact information: e-mail: vs_kornilov@mail.ru 
Olga V. Lvova, candidate of pedagogical sciences, docent, docent of the department of informatization of education of Moscow City Pedagogical University. Contact information: e-mail: olglvova@yandex.ru

Igor S. Obolensky, a physics teacher at school No. 1329 of Moscow. Contact information: e-mail: iograff@gmail.com

Научная статья

\title{
Обучение физике \\ школьников гуманитарно-ориентированных групп по Middle Years Programme (программа основной школы) Международного бакалавриата
}

\author{
В.С. Корнилов ${ }^{1}$, О.В. Львова ${ }^{1}$, И.С. Оболенский ${ }^{2}$ \\ ${ }^{1}$ Московский городской педагогический университет \\ Российская Федерачия, 127521, Москва, ул. Шереметьевская, 29 \\ ${ }^{2}$ Школа № 1389 г. Москвы \\ Российская Федерация, 119602, Москва, ул. Никулинская, 10
}

Проблема и цель. В 1968 году в Швейцарии была создана международная неправительственная организация Международного бакалавриата с консультационным статусом в ЮНЕСКО [11; 26; 27; 29-31]). Методологической основой Международного бакалавриата выступают межкультурное общение, коммуникации, саморазвитие, концептуальное мышление, эффективность обучения и др. Международный бакалавриат является международно признанной учебной программой и реализуется по всему миру, в том числе и в России (Владивосток, Москва, Московская область, Пермь, Самара, Санкт-Петербург, Ульяновск). Кроме того, дипломы Международного бакалавриата признаются многими иностранными учебными заведениями.

В процессе обучения физике школьников гуманитарно-ориентированных групп по программе МYР (основная школа) Международного бакалавриата у некоторых школьников появляются трудности как при усвоении теоретического материала, так и при решении учебных текстовых задач.

В связи с чем для повышения эффективности обучения таких школьников целесообразно не только проводить теоретическое обоснование возможностей использования методов адаптации текстов задач по физике и разрабатывать адаптированные учебные задачи с последующим их включением в содержание обучения, но и использовать современные информационные технологии при изложении школьникам теоретического материала (мультимедийные средства обучения, электронные ресурсы и др.), а также научить школьников использовать компьютерные программы («Живая физика», «Лаборатория L-микро», «1C: Репетитор по физике», «Курс физики XXI века», «Открытая физика», «Физика в анимациях», «Физика. 7-11 классы. Практикум» и др.).

Очевидно, что необходимо в дальнейшем проводить и экспериментальную педагогическую деятельность, выявляющую эффективность такого обучения физике.

Методология. Эффективность обучения физике школьников гуманитарно-ориентированных групп по программе МYР (основная школа) Международного бакалавриата во многом будет обеспечиваться разработанным содержанием обучения, реализацией дидактических принципов обучения и системно-деятельностного подхода в обучении, 
информатизацией обучения, лингвистическим анализом содержания учебных задач, реализацией технологического подхода к конструированию учебного процесса обучения, учетом особенностей психологических закономерностей формирования умственных действий школьников в процессе решения физических задач $[1 ; 3 ; 7-9 ; 12-16 ; 19 ; 20 ; 28]$.

Результаты. Применение методики адаптации текста учебных задач, использование средств информатизации и различных алгоритмов решения физических задач, лингвистический анализ содержания учебных задач способствуют повышению качества обучения физике школьников гуманитарно-ориентированных групп по программе MYP (основная школа) Международного бакалавриата.

Заключение. Использование адаптированного формата представления учебных задач, различных алгоритмов решения физических задач, применение современных информационных технологий для обучения физике школьников гуманитарно-ориентированных групп по программе МYР (основная школа) Международного бакалавриата способствуют повышению у школьников заинтересованности в обучении и формированию у них фундаментальной системы предметных знаний по физике.

Ключевые слова: Middle Years Programme (программа основной школы); Международный бакалавриат; информационные технологии; информатизация обучения физике; алгоритмы решения физических задач; школьники гуманитарно-ориентированных групп

\section{Список литературы}

[1] Бабанский Ю.К. Оптимизация процесса обучения. М.: Педагогика, 2007. 103 с.

[2] Божович Л.И. Личность и ее формирование в детском возрасте. СПб.: Питер. 2008. $400 \mathrm{c}$.

[3] Боровских T.A. Конструирование учебного процесса на основе технологического подхода // Интеграция образования. 2011. № 1 (62). С. 67-73.

[4] Генденштейн Л.Э., Булатова А.А., Корнильев И.Н., Кошкина А.В. Физика. 9 класс: учебник: в 2 ч. Ч. 1. М.: Лаборатория знаний. 2019. 224 с.

[5] Генденштейн Л.Э., Булатова А.А., Корнильев И.Н., Кошкина А.В. Физика. 9 класс: учебник: в 2 ч. Ч. 2. М.: Лаборатория знаний. 2019. 144 с.

[6] Генденштейн Л.Э., Кайдалов А.Б., Кожевников В.Б. Физика 9 класс: учебник. М.: Мнемозина, 2012. $273 \mathrm{c}$.

[7] Гриншкун В.В. Качество информационных ресурсов и профессиональные качества педагогов. Взаимосвязь и проблемы // Информатика и образование. 2013. № 1 (240). С. 79-81.

[8] Гриншкун B.B. Информатизация как значимый компонент совершенствования системы подготовки педагогов // Вестник Московского городского педагогического университета. Серия: Информатика и информатизация образования. 2014. № 1 (27). C. $15-21$.

[9] Гриншкун B.B. Существующие подходы к использованию средств информатизации при обучении естественно-научным дисциплинам // Вестник Московского городского педагогического университета. Серия: Информатика и информатизация образования. 2014. № 4 (30). С. 8-13.

[10] Дуэк К. Гибкое сознание: новый взгляд на психологию развития взрослых и детей. М.: Манн, Иванов и Фербер, 2013. 400 с.

[11] Кондаков А.M. Международный бакалавриат и российская школа: нормативно-методическая документация для российских образовательных учреждений. М.: Молодая гвардия, $1997.51 \mathrm{c}$. 
[12] Корнилов В.С. Методы рациональных рассуждений в обучении обратным задачам для дифференциальных уравнений // Вестник Московского городского педагогического университета. Серия: Информатика и информатизация образования. 2005. № 2 (5). C. 63-66.

[13] Корнилов В.С. Гуманитарная компонента прикладного математического образования // Вестник Московского городского педагогического университета. Серия: Информатика и информатизация образования. 2006. № 2 (7). С. 94-99.

[14] Корнилов B.C. Обратные задачи в содержании обучения прикладной математике // Вестник Российского университета дружбы народов. Серия: Информатизация образования. 2014. № 2. С. 109-118.

[15] Корнилов В.С. Реализация научно-образовательного потенциала обучения студентов вузов обратным задачам для дифференциальных уравнений // Казанский педагогический журнал. 2016. № 6. С. 55-59.

[16] Корнилов В.С. Теория и методика обучения обратным задачам для дифференциальных уравнений: монография. М.: ОнтоПринт, 2017. 500 с.

[17] Кривченко И.В. Физика 9 класс: учебник. М.: Лаборатория знаний. 2015. 150 с.

[18] Левшунова Ж.А., Артюхова Т.Ю. Возрастные особенности осознанной саморегуляции произвольной активности в период ранней юности // Вестник Кемеровского государственного университета. 2015. Т. 1. № 3. С. 102-106.

[19] Мирошкина M.P. X, У, Z. Теория поколений. Новая система координат // Вопросы воспитания. 2014. № 2. С. 50-57.

[20] Пенроуз Р. Новый ум короля: о компьютерах, мышлении и законах физики. М.: УРСС, 2011. $400 \mathrm{c}$.

[21] Перышкин А.В. Физика: 9 класс: сборник задач по физике. М.: Экзамен, 2010. 195 с.

[22] Перышкин А.В. Физика: 8 класс. М.: Дрофа, 2013. 237 с.

[23] Перышкин А.В., Лонизова Г.А. Физика: 8 класс: учебник. М.: Дрофа, 2017. 160 с.

[24] Федеральный государственный образовательный стандарт основного общего образования: утв. приказом Минобрнауки РФ от 29 декабря 2014 г. № 1644. URL: http://www.edu.ru/db/mo/Data/d_14/m1644.html (дата обращения: 20.03.2019).

[25] Федеральный закон об образовании в Российской Федерации: утв. приказом Государственной думы РФ от 29 декабря 2012 г. № 273-ФЗ (ред. от 03.08.2018). URL: http://www.consultant.ru/document/cons_doc_LAW_140174/ (дата обращения: 20.03.2019).

[26] Что такое международный бакалавриат и как работает наша школа. URL: https:// infourok.ru/chto-takoe-mezhdunarodniy-bakalavriat-i-kak-rabotaet-nasha-shkola3160569.html (дата обращения: 20.03.2019).

[27] Что такое программа Международного бакалавриата (IB)? URL: https://www. globaldialog.ru/articles/chto-takoe-ib/ (дата обращения: 20.03.2019).

[28] Эсаулов А.Ф. Психология решения задач. М.: Высшая школа, 1972. 217 с.

[29] IB Middle Years Programme. URL: https://istudy.com.ru/ib/ib-myp.html (дата обращения: 20.03.2019).

[30] MYP: from principles into practice. URL: http://www.ibo.org/ (дата обращения: 20.03.2019).

[31] MYP Science guide. URL: https://www.spps.org/site/handlers/ filedownload.ashx?mod uleinstanceid $=38378 \&$ dataid=21234\&FileName=sciences_guide_2014.pdf (дата обращения: 20.03.2019).

\section{История статьи:}

Дата поступления в редакцию: 10 апреля 2019

Дата принятия к печати: 20 мая 2019 


\section{Для цитирования:}

Kornilov V.S., Lvova O.V., Obolensky I.S. Teaching physics students of humanitarianoriented groups in the Middle Years Programme (basic school) of the International Baccalaureate (Обучение физике школьников гуманитарно-ориентированных групп по Middle Years Programme (программа основной школы) Международного бакалавриата // Вестник Российского университета дружбы народов. Серия: Информатизация образования. 2019. Т. 16. № 3. С. 270-280. http://dx.doi.org/10.22363/2312-8631-2019-16$3-270-280$

\section{Сведения об авторах:}

Корнилов Виктор Семенович, доктор педагогических наук, кандидат физико-математических наук, профессор, профессор кафедры информатизации образования Московского городского педагогического университета. Контактная информащия: e-mail: vs_kornilov@mail.ru

Львова Ольга Владимировна, кандидат педагогических наук, доцент, доцент кафедры информатизации образования Московского городского педагогического университета. Контактная информация: e-mail: olglvova@yandex.ru

Оболенский Игорь Сергеевич, учитель физики школы № 1329 г. Москвы. Контактная информация: e-mail: iograff@gmail.com 